\title{
GAMBARAN Ph SALIVA ANAK-ANAK MADRASAH IBTIDAIYAH DARUL ISTIQAMAH BAILANG
}

\author{
${ }^{1}$ Steffi Ch. Sambow \\ ${ }^{2}$ Jimmy Abidjulu \\ ${ }^{2}$ Paulina Gunawan
}

\author{
${ }^{1}$ Kandidat Skripsi Program Studi Kedokteran Gigi Fakultas Kedokteran \\ Universitas Sam Ratulangi Manado \\ ${ }^{2}$ Program Studi Kedokteran Gigi Fakultas Kedokteran Universitas Sam Ratulangi Manado \\ Email: Steffi_christina@yahoo.com
}

\begin{abstract}
Dental caries is a dominant oral health problems in indonesia, caused by demineralization of dental hard tissue. Saliva is a natural protective factor againts caries that can be stimulated by chewing gum containing xylitol. The purpose of this study is to describe the $\mathrm{pH}$ of saliva before and after eating xylitol chewing gum. This type of research is the study of clinical trials, the experimental study with a pretest-posttest design. The tota sample of 45 children Madrasah Ibtidaiyah Darul Istiqamah Bailang the class 3,4,5 and 6. Examination of saliva pH performed 4 times, is before consuming xylitol chewing gum, 5 minutes, 10 minutes, and 15 minutes after eating xylitol chewing gum. Conducted to consume xylitol chewing gum for 5 minutes. Salivary $\mathrm{pH}$ was measured using a $\mathrm{pH}$ meter scale from 0-14. Data analysis using the description of the characteristics of the data obtained from the research. Result of this study showed an average $\mathrm{pH}$ of saliva before consuming xylitol gum is 7,24 and the average yield $\mathrm{pH}$ saliva after consumption of xylitol chewing gum for 5 minutes is 7,48, 7,40 minutes 10 and minute 15 is to 7,32. Conclusion: There was an increase in salivary $\mathrm{pH}$ after consumption of xylitol chewing gum because this gum stimulated saliva secretion.
\end{abstract}

Keywords: xylitol chewing gum, $\mathrm{pH}$ saliva

\begin{abstract}
Abstrak: Karies gigi merupakan masalah kesehatan gigi dan mulut yang dominan di indonesia, disebabkan oleh proses demineralisasi jaringan keras gigi. Saliva adalah faktor pelindung alami terhadap karies yang dapat distimulasi oleh pengunyahan permen karet yang mengandung xylitol. Penelitian ini bertujuan untuk mengetahui gambaran $\mathrm{pH}$ saliva yaitu sebelum dan setelah mengonsumsi permen karet xylitol. Jenis penelitian yang digunakan ialah penelitian uji klinis dengan rancangan eksperimental pretest-posttest. Jumlah sampel sebanyak 45 orang anak Madrasah Ibtidaiyah Istiqamah Bailang yaitu kelas 3,4,5 dan 6. Pemeriksaan $\mathrm{pH}$ saliva dilakukan sebanyak 4 kali, yaitu sebelum mengonsumsi permen karet xylitol, kemudian 5 menit, 10 menit, dan 15 menit setelah mengonsumsi permen karet xylitol. Mengonsumsi permen karet xylitol dilakukan selama 5 menit. pH saliva diukur menggunakan $\mathrm{pH}$ meter yang berskala 0,0-14. Analisis data menggunakan gambaran tentang karakteristik data yang didapatkan dari hasil penelitian. Hasil penelitian menunjukkan ratarata $\mathrm{pH}$ saliva sebelum mengonsumsi permen karet xylitol yaitu 7,24, dan hasil rata-rata $\mathrm{pH}$ saliva setelah mengonsumsi permen karet xylitol menit ke 5 yaitu 7,48, menit ke 10 menjadi 7,40 dan menit ke 15 menjadi 7,32. Simpulan: Terjadinya peningkatan $\mathrm{pH}$ saliva setelah mengonsumsi permen karet xylitol disebabkan karena permen tersebut dapat menstimulasi sekresi saliva.
\end{abstract}

Kata kunci: permen karet xylitol, pH saliva 
Saliva merupakan lapisan biologis yang menyelubungi seluruh permukaan jaringan di dalam rongga mulut. ${ }^{1}$ Saliva sebagian besar yaitu sekitar 90 persennya dihasilkan saat makan yang merupakan reaksi atas rangsangan yang berupa pengecapan dan pengunyahan makanan. ${ }^{2}$ Fungsinya tidak hanya dalam membantu pengunyahan, tetapi juga dalam melindungi jaringan di dalam rongga mulut. Fungsi proteksi dari saliva ini akan menjaga keseimbangan di dalam rongga mulut, terutama terhadap faktor-faktor yang menyebabkan kerusakan gigi seperti karies gigi. ${ }^{1}$ Cara perlindungan yang dilakukan saliva bisa berupa mengatur $\mathrm{pH}$ rongga mulut karena mengandung bikarbonat, fosfat, dan protein amfoter. Peningkatan kecepatan sekresinya biasanya berakibat pada peningkatan pH dan kapasitas bufernya. Membrana mukosa akan terlindung dari asam yang ada pada makanan. Selain itu, penurunan $\mathrm{pH}$ plak sebagai akibat ulah organisme yang asidogenik, akan dihambat. ${ }^{3}$

Keasaman $(\mathrm{pH})$ saliva merupakan salah satu faktor penting yang dapat mempengaruhi proses terjadinya demineralisasi pada permukaan gigi. Perubahan $\mathrm{pH}$ saliva dipengaruhi oleh susunan kuantitatif dan elektrolit dan kapasitas bufer di dalam saliva. Dalam keadaan normal, pH saliva berkisar antara 6,8-7,2. ${ }^{4}$ Sisa karbohidrat yang tertinggal di dalam rongga mulut akan difermentasikan oleh bakteri patogen rongga mulut sehingga dihasilkan asam yang akan menurunkan pH saliva. ${ }^{5}$

Xylitol merupakan alkohol gula yang rasa manisnya sama dengan gula sukrosa dan menghasilkan kalori dalam jumlah yang sama dengan sukrosa yaitu 4 kal/gr. Nama lain xylitol adalah pentitol, pentose, polyalkohol dan polyol. ${ }^{6}$ Xylitol memiliki efek dingin pada mulut ketika dikonsumsi dan rasa manis seperti sukrosa meskipun tingkat energinya tidak sama. Mekanisme aksi xylitol adalah dengan mengurangi produk asam bakteri secara signifikan, menstimulasi laju aliran saliva dan meningkatkan kemampuan penyangga saliva, menghambat akumulasi plak dan bakteri kariogenik, remineralisasi pada area yang mengalami dekalsifikasi dan menghambat demineralisasi email yang masih sehat. ${ }^{7}$ Penelitian ini bertujuan untuk mengetahui gambaran $\mathrm{pH}$ saliva anak-anak Madrasah Ibtidaiyah Darul Istiqamah Bailang sebelum dan setelah mengonsumsi permen karet xylitol pada menit ke-5, menit ke-10, dan menit ke-15.

\section{BAHAN DAN METODE}

Penelitian ini merupakan peneilitian uji klinis dengan menggunakan rancangan eksperimental pretest-posttest. Pengambilan sampel pada penelitian ini yaitu mengambil semua siswa yang termasuk dalam kriteria sampel untuk dijadikan sebagai sampel yaitu sebanyak 45 orang. Pengumpulan data didahului dengan survei awal dan permohonan untuk izin penelitian ini diperoleh dari persetujuan pihak sekolah, serta izin persetujuan atau informed consent kepada masing-masing orang tua. Setelah mendapat izin dari pihak sekolah dan orang tua maka pelaksanaan penelitian akan dimulai. Dilakukan pemeriksaan dengan menggunakan alat $\mathrm{pH}$ meter untuk mendapatkan data tentang gambaran $\mathrm{pH}$ saliva sebelum dan setelah mengonsumsi permen karet xyltiol. $\mathrm{pH}$ meter ini berskala 0-14 dengan perbandingan terbalik, dimana makin rendah nilai $\mathrm{pH}$ makin banyak asam 
dalam saliva. Sebaliknya, meningkatnya nilai $\mathrm{pH}$ berarti bertambahnya basa dalam saliva. ${ }^{8}$ Suatu larutan dikatakan asam jika $\mathrm{pH}<7$ sedangkan dikatakan basa jika $\mathrm{pH}>7$. $\mathrm{pH}$ saliva yang terstimulasi dan tidak terstimulasi biasanya akan berbeda hingga dua menit dan berkisar antara 5,3-7,8. ${ }^{7}$

Tabel 1

\begin{tabular}{lcccc}
\hline & $\begin{array}{c}\text { Saliva sebelum } \\
\text { terstimulasi } \\
(\mathrm{pH})\end{array}$ & \multicolumn{3}{c}{$\begin{array}{c}\text { Saliva terstimulasi } \\
(\mathrm{pH})\end{array}$} \\
\hline Jumlah sampel & 45 & 5 menit & 10 menit & 15 \\
Minimum & 6,99 & 45 & 45 & 45 \\
Maksimum & 7,41 & 7,30 & 7,24 & 7,11 \\
Mean (rata-rata) & 7,24 & 7,68 & 7,59 & 7,48 \\
\hline
\end{tabular}

Pada tabel 1. pH terendah pada pengukuran pH saliva sebelum mengonsumsi permen karet xylitol yaitu 6,99 sedangkan pH tertinggi 7,41 dengan nilai mean (rata-rata) 7,24. Pada pengukuran $\mathrm{pH}$ terendah saliva setelah mengonsumsi permen karet xylitol selama 5 menit yaitu 7,30 sedangkan $\mathrm{pH}$ tertinggi 7,68 dengan nilai mean (rata-rata) 7,48. Pengukuran $\mathrm{pH}$ terendah setelah 10 menit mengonsumsi permen karet xylitol yaitu 7,24 sedangkan $\mathrm{pH}$ tertinggi 7,59 dengan nilai mean (ratarata) 7,40. Pengukuran $\mathrm{pH}$ terendah setelah 15 menit mengonsumsi permen karet xylitol yaitu 7,11 sedangkan pH tertinggi 7,48 dengan nilai mean (rata-rata) 7,32.

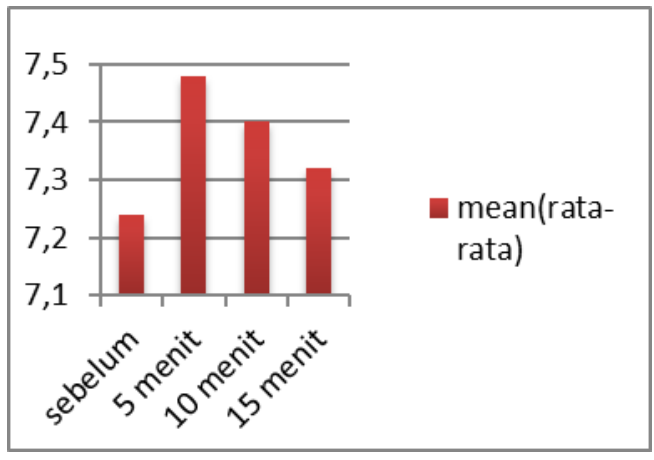

Gambar 1. Hasil rata-rata pengukuran $\mathrm{pH}$ saliva

Pada Gambar 1 terlihat nilai rata-rata ph saliva pada keadaan awal/sebelum terstimulasi 7,24. Setelah mengonsumsi permen karet xylitol selama 5 menit nilai rata-rata $\mathrm{pH}$ saliva meningkat menjadi 7,48. Pada menit ke 10 dan ke 15 nilai rata-rata $\mathrm{pH}$ saliva meningkat tetapi berangsur turun menjadi 7,40 dan 7,32. 


\section{BAHASAN}

Keasaman $(\mathrm{pH})$ saliva merupakan salah satu faktor penting yang dapat mempengaruhi proses terjadinya demineralisasi pada permukaan gigi. Perubahan $\mathrm{pH}$ saliva dipengaruhi oleh susunan kuantitatif dan kualitatif elektrolit dan kapasitas buffer di dalam saliva. Dalam keadaan normal, pH saliva berkisar antara 6,8-7,2. ${ }^{4}$

Xylitol merupakan substansi gula dengan kemanisan yang sama dengan kemanisan sukrosa dan memiliki kalori yang lebih kecil 40\% dari sukrosa. Nilai kalori dari xylitol adalah berkisar 2,4 kal/gr atau lebih rendah. Xylitol merupakan sejenis pemanis polyols yang bersifat non-asidogenik dan nonkariogenik.

Penelitian eksperimental klinis ini dilakukan untuk melihat gambaran xylitol terhadap $\mathrm{pH}$ saliva anak-anak Madrasah Ibtidaiyah Istiqamah Bailang yang dilihat dari $\mathrm{pH}$ saliva sebelum dan setelah mengonsumsi permen karet xylitol yaitu 5 menit, 10 menit, dan 15 menit. Pemeriksaan pH saliva dilakukan sebelum dan setelah mengonsumsi permen karet xylitol untuk mengetahui perubahan $\mathrm{pH}$ saliva yang terjadi.

Hasil penelitian ini yang dilakukan terhadap 45 orang anak di Madrasah Ibtidaiyah Darul Istiqamah Bailang, menunjukkan bahwa mengonsumsi permen karet yang mengandung xylitol selama 5 menit, dapat meningkatkan pH saliva selama 5 menit, 10 menit dan 15 menit. Pernyataan tersebut dapat dilihat dari hasil $\mathrm{pH}$ saliva sebelum mengonsumsi permen karet (pH awal) dan setelah mengonsumsi permen karet xylitol selama 5 menit, 10 menit, dan 15 menit.

Pada tabel 1. $\mathrm{pH}$ terendah pada pengukuran $\mathrm{pH}$ saliva sebelum mengonsumsi permen karet xylitol 6,99 sedangkan $\mathrm{pH}$ tertinggi 7,41 dengan nilai mean (rata-rata) 7,24. Pada pengukuran $\mathrm{pH}$ terendah saliva setelah mengonsumsi permen karet xylitol selama 5 menit yaitu 7,30 sedangkan $\mathrm{pH}$ tertinggi 7,68 dengan nilai mean (rata-rata) 7,48. Pengukuran $\mathrm{pH}$ terendah setelah 10 menit mengonsumsi permen karet xylitol yaitu 7,24 sedangkan pH tertinggi 7,59 dengan nilai mean (ratarata) 7,40. Pengukuran $\mathrm{pH}$ terendah setelah 15 menit mengonsumsi permen karet xylitol yaitu 7,11 sedangkan pH tertinggi 7,48 dengan nilai mean (rata-rata) 7,32. Pada subyek setelah mengonsumsi permen karet xylitol dinyatakan bahwa hasil analisa data sesuai dengan teori bahwa terjadinya perubahan yang signifikan pada nilai $\mathrm{pH}$ saliva awal atau sebelum mengonsumsi permen karet xylitol dengan nilai saliva setelah mengonsumsi permen karet xylitol selama 5 menit, 10 menit dan 15 menit disebabkan karena pada subyek perlakuan diberikan stimulus kelenjar saliva berupa permen karet yang mengandung xylitol sebanyak 1 buah.

Pada gambar 3 terlihat adanya peningkatan pada nilai $\mathrm{pH}$ saliva sebelum mengonsumsi permen karet xylitol (pH saliva awal) dengan setelah mengonsumsi permen karet yang mengandung xylitol yaitu 5 menit, 10 menit, dan 15 menit. Peningkatan tersebut terjadi akibat stimulasi kelenjar saliva yang membuat peningkatan laju aliran saliva, sehingga terjadi peningkatan pada nilai pH saliva. Selain itu, adanya rasa manis juga dapat merangsang kelenjar saliva untuk memproduksi saliva sehingga laju alir saliva meningkat, hal ini sesuai dengan teori yang menyatakan bahwa rasa manis 
dari gula dapat menstimulasi kelenjar saliva. ${ }^{9}$ Mengonsumsi permen karet yang mengandung xylitol terbukti dapat menetralkan kembali $\mathrm{pH}$ yang rendah dengan meningkatkan kapasitas dapar saliva dan meningkatkan pembersihan dari rongga mulut melalui aliran saliva. ${ }^{10}$

Mengonsumsi permen karet xylitol mempunyai kelebihan dalam menjaga kesehatan mulut, yaitu meningkatkan $\mathrm{pH}$ saliva, serta meningkatkan sekresi saliva. Pernyataan tersebut sejalan dengan penelitian Harris (2004) bahwa mengonsumsi permen karet yang mengandung xylitol yang megandung gula ataupun bebas gula merupakan cara yang efektif untuk meningkatkan laju aliran saliva. ${ }^{11}$ Menurut penelitian Dewi (2008), xylitol lebih efektif daripada gula terhadap kesehatan mulut karena xylitol tidak dimetabolisme oleh bakteri dalam pembentukkan asam dan mempunyai efek antibakteri, mengonsumsi permen karet xylitol juga dapat menurunkan jumlah bakteri mulut di dalam plak dan saliva. Oleh karena itu selama mengonsumsi permen karet yang mengandung xylitol derajat keasaman saliva akan naik, produksi saliva dapat mengurangi endapan sisa makanan di permukaan gigi. Bahan-bahan yang terkandung dalam permen karet xylitol

seperti enzim dan bikarbonat dapat memicu remineralisasi enamel gigi. ${ }^{12}$

Mengonsumsi permen karet xylitol mempunyai kelebihan dalam menjaga kesehatan mulut yaitu, meningkatkan $\mathrm{pH}$ saliva, serta meningkatkan sekresi saliva. Pernyataan tersebut didukung oleh penelitian Kauko (2008) bahwa saliva yang mengandung xylitol memiliki sifat lebih basa dibandingkan degan saliva yang distimulasi oleh gula lainnya. ${ }^{13}$ Menurut penelitian yang dilakukan oleh Purba (2009) yaitu penelitian tersebut menghasilkan $\mathrm{p}<0,05$ yang dapat disimpulkan bahwa permen karet yang mengandung xylitol dapat meningkatkan $\mathrm{pH}$ saliva. ${ }^{14}$ Permen karet bebas gula adalah cara yang sangat praktis untuk merangsang saliva setelah mengonsumsi makanan yang mengandung gula. ${ }^{15}$

\section{SIMPULAN}

Hasil pengukuran pH saliva rata-rata sebelum mengonsumsi permen karet xylitol yaitu 7,24. Hasil pengukuran $\mathrm{pH}$ saliva rata-rata setelah mengonsumsi permen karet xylitol pada menit ke-5 yaitu 7,48 pada menit ke-10 pH saliva rata-rata 7,40 dan pada menit ke-15 di dapat pH saliva ratarata 7,32 .

\section{SARAN}

a. Bagi Pemerintah

Dapat memberikan masukan bagi pemerintah melalui Dinas Kesehatan dalam membuat penyuluhan kesehatan anak dalam peningkatan pelayanan usaha kesehatan sekolah.

b. Bagi Pendidikan

Meningkatkan program pendidikan kesehatan gigi di sekolah, meningkatkan pengetahuan kesehatan gigi dan perawatan gigi, sehingga pengetahuan anak tentang kesehatan gigi dan perawatan gigi dapat meningkat. 


\section{DAFTAR PUSTAKA}

1. Yastina Devina. Perbandingan nilai viskositas, $\mathrm{pH}$, dan kapasitas dapar saliva setelah mengkonsumsi air madu dan air pemanis rendah kalori. Fakultas Kedokteran Gigi. Universitas Indonesia. [Online 2008] [cited April 2013]. Available from: URL: http://lontar.ui.ac.id/file\%3Ffile\%3Ddigital/125149-R18-KON

2. Soesilo Diana, Santoso Erlyawati, dan Diyatri Indeswati. Peranan sorbitol dalam mempertahankan kestabilan pH saliva pada proses pencegahan karies. Maj. Ked. Gigi (Dent. J), vol. 38. No 1 Januari 2005:25-28.

3. Edwina AM, Bechal SJ. Dasar-dasar karies: penyakit dan penanggulangannya. Jakarta: Penerbit buku kedokteran EGC;1991. h. 66-67.

4. Apriyono DK, Fatimatuzzahro N. Pengaruh kumur-kumur dengan larutan triclosan 3\% terhadap pH saliva. CDK187.2011;38(7): 426-428

5. Schuurs BHA, Moorer WR, Andersen BP, Visser JB. Patologi gigi geligi kelainan-kelainan jaringan keras gigi. Suryo S, editor. Yogyakarta: Gadjah Mada University Press; 1992: 135148.

6. Sari Nyi Nyoman Gemini. Permen karet xylitol yang dikunyah selama 5 menit meningkatkan dan mempertahankan pH saliva perokok selama 3 jam. Program Studi Ilmu Biomedik. Program Pascasarjana. Universitas Udayana Denpasar. [Online] 2011 [cited April 2013]; Available from: URL:http://www.pps.unud.ac.id/thesis/pdf_thesis/unud-2971674913399-tesis

7. Satariah Ferigina. Efek xylitol terhadap resiko karies ditinjau dari $\mathrm{pH}$ saliva pada pasien yang menggunakan alat ortodonti cekat. Pendidikan Dokter Gigi, Universitas Indonesia. [Online] 2008 [cited Mar 2013]. Available from:URL: http://lontar.ui.ac.id/file\%3Ffile\%3Ddigital/125300-R19-ORT124\%2520Efek\%2520xylitol-HA.pdf.

8. Angela Ami. Pencegahan primer pada anak yang berisiko karies tinggi. Fakultas Kedokteran Gigi Universitas Sumatera Utara. Maj. Ked. Gigi. (Dent. J.), Vol. 38. No. 3 Juli - September 2005:130-1334.

9. Anonymous. Xylitol. http://en.wikipedia.org/wiki/Xylitol.6/8/2008

10. Thaweboon S, Thaweboon B, Sc Ampon S, The Effect of Xylitol Chewing Gum on Mutans Streptococci in Saliva and Dental Plaque http://www.tm.mahidol.ac.th/seameo/2004/35_4/43-3307.pdf04/12/2008

11. Harris NO, Garcia-Godoy F. Primary Preventive Dentistry $6^{\text {th }}$ ed. New Jersey: Pearson Prentice Hall. 2004: 12: 337-60, 119-37.

12. Dewi Putti F. Pengaruh konsumsi permen karet yang mengandung xylitol terhadap pembentukkan plak gigi. Fakultas Kedokteran. Universitas Diponegoro. Semarang. [Online] 2008 [cited September 2013]. Available from:URL:http:eprints.undip.ac.id/24284/1/Putti.pdf

13. Makinen, Kauko K Hstory, Safety, and Dental. Properties of Xylitol. http://www.xylitol.org/dmakinen.asp.20 juli2008

14. Purba, Merina Rentaini Cesaria. (2009). Perbandingan $\mathrm{pH}$ saliva sebelum dan sesudah menyikat gigi dengan pasta gigi yang mengandung sorbitol dan xylitol pada mahasiswa FKG USU angkatan 2007/2008. http://repositoy.usu.ac.id/bitsream/123456789/16857/6.pdf

15. Holgeston, P.I. 2007. Xylitol and it's effect on oral ecology. Departement of odontology. Paediatric. Dentistry Fakulty od Medicine. umea. Hal.16-20. 
